\title{
COLUMNAR METAPLASIA AND BARRETT'S ESOPHAGUS: MORPHOLOGICAL HETEROGENEITY AND IMMUNOHISTOCHEMICAL PHENOTYPE
}

Mikhaleva $L M^{1,2} \otimes$, Voytkovskaya $K^{2}$, Fedorov ED ${ }^{2,3}$, Gracheva $\mathrm{NA}^{2}$, Birukov $A E^{1,2}$, Shidiy-Zakrua $A V^{3}$, Guschin $M Y^{1}$

${ }^{1}$ Research Institute of Human Morphology, Moscow, Russia

${ }^{2}$ City Clinical Hospital № 31, Moscow, Russia

${ }^{3}$ Pirogov Russian National Research Medical University, Moscow, Russia

\begin{abstract}
Barrett's esophagus (BE) is a pathologically confirmed intestinal metaplasia (CM) of the distal esophagus. BE is recognized as a potential complication of gastroesophageal reflux disease (GERD) and a premalignant condition with a high risk of neoplastic progression. The aim of this study was to compare the morphology of biopsied BE segments and CM segments extending $<1 \mathrm{~cm}$ and $>1 \mathrm{~cm}$ above the gastroesophageal junction (GEJ), as well as to perform the immunohistochemical analysis of biopsies with $\mathrm{BE}$ and $\mathrm{CM}>1 \mathrm{~cm}$ above GEJ with or without dysplasia. The study recruited 92 patients with GERD: 42 patients with $\mathrm{BE}, 24$ patients with $\mathrm{CM}>1 \mathrm{~cm}$ above GEJ (COM1.5-C13M14) and 26 patients with $\mathrm{CM}<1 \mathrm{~cm}$ above GEJ (COM0.3-0.8). Comparative analysis of tissue morphology revealed an association between the reactive changes in the epithelium and the severity of esophagitis in all groups. Reactive changes were detected significantly more often in BE segments than in CM segments $>1 \mathrm{~cm}$ (Mann-Whitney $\mathrm{U}, p<0.05$ ). Eight patients with BE (19.05\%) were found to have lowgrade dysplasia. One patient with $\mathrm{CM}>1 \mathrm{~cm}$ above GEJ (4.2\%) had high-grade dysplasia with cardiac-type metaplasia and immunohistochemical features of submorphological enteralization. Immunohistochemical testing for the intestinal and gastric markers of cell differentiation revealed the signs of submorphological enteralisation in all esophageal specimens with cardiac and fundic type metaplasia and in the specimens with BE in the areas lacking goblet cells.
\end{abstract}

Keywords: columnar metaplasia, Barrett's esophagus, low-grade dysplasia, high-grade dysplasia, carcinogenesis

Author contribution: Mikhaleva LM — planned and supervised the study; provided equipment for the study; analyzed the obtained results; Voytkovskaya KS — analyzed the literature; collected, analyzed and interpreted the obtained data; processed microphotographs and wrote the manuscript; Fedorov ED — examined the patients; performed EGD and biopsy; analyzed and summarized the data; Shidiy-Zakrua AV — examined the patients, performed EGD and biopsy; Birukov AE — and Gracheva NA — performed pathological examination; Guschin MY — analyzed the literature.

Compliance with ethical standards: all patients gave written informed consent

$\triangle$ Correspondence should be addressed: Ludmila M. Mikhaleva

Tsyuryupy 3, Moscow, 117418; mikhalevalm@yandex.ru

Received: 03.12.2019 Accepted: 18.12.2019 Published online: 25.12.2019

DOI: $10.24075 /$ brsmu.2019.086

\section{ЦИЛИНДРОКЛЕТОЧНАЯ МЕТАПЛАЗИЯ И ПИЩЕВОД БАРРЕТТА: МОРФОЛОГИЧЕСКАЯ НЕОДНОРОДНОСТЬ И ИММУНОГИСТОХИМИЧЕСКИЙ ФЕНОТИП}

Л. М. Михалева ${ }^{1,2}$, К. С. Войтковская² , Е. Д. Федоров ${ }^{2,3}$, Н. А. Грачева ${ }^{2}$ А. Е. Бирюков ${ }^{1,2}$, А. В. Шидии-Закруа ${ }^{3}$, М. Ю. Гущин ${ }^{1}$

${ }^{1}$ Научно-исследовательский институт морфологии человека, Москва, Россия

2 Городская клиническая больница № 31, Москва, Россия

${ }^{3}$ Российский национальный исследовательский медицинский университет имени Н. И. Пирогова, Москва, Россия

Пищевод Барретта (ПБ), или доказанная морфологически кишечная метаплазия слизистой оболочки дистального отдела пищевода, является облигатным предраковым заболеванием, которое развивается как осложнение гастроэзофагеальной рефлюксной болезни (ГЭРБ). Цель исследования — выполнить сравнительный морфологический анализ биопсированных фрагментов ПБ, ЦМ на расстоянии < 1 см и > 1 см от гастроэзофагеального перехода (ГЭП), а также провести иммуногистохимическое исследование фрагментов с ПБ и ЦМ > 1 см от ГЭП при наличии и отсутствии дисплазии. В исследование вошли 92 пациента с ГЭРБ: 42 пациента с ПБ, 24 пациента с ЦМ > 1 см от ГЭП (СОМ1,5 до С13М14) и 26 пациентов с ЦМ < 1 см от ГЭП (СОМО,3-0,8). При сравнительном морфологическом анализе наличие реактивных изменений эпителия было связано с тяжестью эзофагита во всех группах. Реактивные изменения эпителия выявляли достоверно чаще при ПБ по сравнению с ЦМ > 1 см от ГЭП ( $p<0,05$ при использовании критерия Манна-Уитни). При ПБ в восьми наблюдениях (19,05\%) выявлена low-grade дисплазия. В одном наблюдении ЦМ > 1 см от ГЭП (4,2\%) выявлена high-grade дисплазия на фоне кардиальной метаплазии с иммуногистохимическими признаками субморфологической энтерализации. При иммуногистохимическом исследовании с маркерами желудочной и кишечной дифференцировки признаки субморфологической энтерализации выявлены во всех фрагментах пищевода с кардиальной метаплазией и у пациентов с ПБ в зонах с отсутствием бокаловидных клеток.

Ключевые слова: цилиндроклеточная метаплазия пищевода, пищевод Барретта, low-grade и high-grade дисплазия, канцерогенез

Информация о вкладе авторов: Л. М. Михалева - планирование и руководство исследованием, предоставление материально-технической базь для проведения исследования, анализ результатов; К. С. Войтковская - анализ литературы, сбор, анализ и интерпретация данных, подготовка микрофотографий и рукописи; Е. Д. Федоров - клиническое обследование пациентов, выполнение ЭГДС с взятием биопсийного материала, анализ и обобщение полученных данных; А. В. Шидии-Закруа — клиническое обследование пациентов, выполнение ЭГДС с взятием биопсийного материала; А. Е. Бирюков - исследование и анализ биопсийного материала; Н. А. Грачева — исследование и анализ биопсийного материала; М. Ю. Гущин - сбор и анализ литературы.

Соблюдение этических стандартов: все пациенты подписали добровольное информированное согласие.

$\triangle$ Для корреспонденции: Людмила Михайловна Михалева ул. Цюрупы, д. 3, г. Москва, 117418; mikhalevalm@yandex.ru

Статья получена: 03.12.2019 Статья принята к печати: 18.12.2019 Опубликована онлайн: 25.12.2019

DOI: $10.24075 /$ vrgmu.2019.086 
Barrett's esophagus (BE) refers to intestinal metaplasia (CM) of the distal esophagus confirmed by endoscopy and histological examination. BE is recognized as a potential complication of gastroesophageal reflux disease (GERD) and a premalignant condition with a high risk of neoplastic progression. At present, there is no universally accepted definition of BE because the affected tissue is very heterogeneous and can present as a mosaic of various metaplastic phenotypes within one biopsied fragment of the distal esophageal mucosa. The American Gastroenterological Association maintains that BE should be diagnosed only in the presence of intestinal metaplasia in the biopsies collected from the sites of the columnar-lined esophagus [1]. The British Society of Gastroenterology (BSG) defines BE as any type of columnar metaplasia (CM) extending $\geq 1 \mathrm{~cm}$ above the gastroesophageal junction (GEJ) [2]. The International Consensus BOB CAT group (2015) recognizes $\mathrm{BE}$ as any type of $\mathrm{CM}$ of the distal esophagus but emphasizes that the type of metaplasia should be clearly specified in the pathology report [3].

Embraced by many clinicians, the definition formulated by BSG has become fairly popular. But of course, it did not make the underlying biology of the disease any different. Therefore, for the sake of diagnostic accuracy, it is essential to meticulously compare endoscopy and pathology findings, especially for biopsies collected $<1 \mathrm{~cm}$ above GEJ [4].

In the distal esophagus, 3 types of metaplasia can be distinguished, including cardiac, fundic and intestinal. The first is often seen in short-segment BE and is the earliest metaplastic transformation of the esophagus in patients with GERD. In cardiac-type metaplasia, squamous epithelium is replaced with foveolar cells. Fundic-type metaplasia is characterized by the presence of chief and parietal cells as normally in the gastric corpus mucosa. Intestinal metaplasia usually presents as a patchwork of goblet and foveolar cells and sometimes Paneth cells [5].

Biopsies of one and the same patient can contain different types of columnar-lined epithelium. As a rule, intestinal metaplasia affects the proximal side of columnar-lined esophagus, whereas cardiac and fundic types usually occur more distally, close to GEJ. Intestinal metaplasia is reported to be twice as prevalent in the biopsies from the proximal side of columnar-lined esophagus than in the fragments close to GEJ [6].

Today, the pathogenesis of esophageal $\mathrm{CM}$ is linked to the transdifferentiation of the stratified squamous epithelium or to the transcommitment of progenitor cells involved in the repair of reflux-induced damage [7].

The prevalence of goblet cells is associated with the $\mathrm{pH}$ gradient along the $\mathrm{BE}$ segment: the lower the $\mathrm{pH}$ value (i.e. the closer to GEJ), the fewer and more scattered the goblet cells. This phenomenon might be tied to the solubility gradient of bile acids determined by $\mathrm{pH}$ levels: at more acidic $\mathrm{pH}$ (closer to GEJ) the solubility of bile acids is the lowest; at neutral pH typical of the proximal BE, the solubility of bile acids increases [8]. A study conducted in mice has shown the role of bile acids in the pathogenesis of BE with intestinal metaplasia and CDX2/ MUC2 expression [9].

Another study has demonstrated that cardiac CM can undergo early enteralization, i.e. retain morphological features of cardiac-type cells but start expressing markers of intestinal differentiation, such as Villin and CDX2 [10].

There is ongoing debate about whether goblet cells play an exclusive role in carcinogenesis in the distal esophagus or other $\mathrm{CM}$ types can also contribute to dysplasia and development of esophageal adenocarcinoma. In one of epidemiological studies, the incidence of progression to malignancy in patients with intestinal metaplasia was higher (0.38\% per year) than in patients without this condition (0.07\% per year) [11]. However, this trend was not corroborated by another long-term observation (8-20 years) [12]. In over 70\% of patients with small $(<2 \mathrm{~cm})$ esophageal adenocarcinomas, cancer was preceded by columnar metaplasia of the esophagus, but the metaplastic transformation of mucosa adjacent to the tumor was not intestinal but cardiac [13]. These findings were confirmed by other researchers [14] who reported expression of gastric markers (MUC5A and MUC6) in minute Barrett's tumors ( $<5 \mathrm{~mm}$ ). Non-goblet cardiac-type CM epithelium without CDX2 expression can also undergo malignant transformation [15]. At the same time, high density of goblet cells can reduce the risk of adenocarcinoma $[16,17]$. Perhaps, there are two independent carcinogenesis pathways in the distal esophagus: foveolar and intestinal, i.e. involving both gastric-type and specialized intestinal metaplasia [18-20]. The implicated type of carcinogenesis can be identified by immunohistochemistry from the expression of gastric (MUC1, MUC5A, MUC6) and intestinal (MUC2, CD10, CDX2, Villin, etc.) markers.

According to the definition proposed by BSG, BE should be diagnosed if the metaplastic epithelium extends $\geq 1 \mathrm{~cm}$ above GEJ. Although this criterion is increasingly applied, it is still arbitrary. So far, research into the contribution of ultrashort $\mathrm{BE}(<1 \mathrm{~cm})$ to esophageal carcinogenesis has produced conflicting evidence.

The aim of this study was to compare the morphology of columnar-lined esophagus segments extending $<1 \mathrm{~cm}$ above GEJ (ultra-short BE), classic goblet BE and CM extending $>1 \mathrm{~cm}$ above GEJ, to identify the relative prevalence of different metaplasia types, the frequency of reactive changes in the epithelium (indefinite for metaplasia) and dysplasia of the metaplastic esophageal epithelium, as well as to carry out the immunohistochemical analysis of BE specimens with different types of metaplastic transformations with or without dysplasia.

\section{METHODS}

The study was carried out at the City Clinical Hospital № 31 between January 1, 2018 and September 1, 2019. The study recruited patients with GERD who were undergoing medical examination at the Hospital at that time. The following inclusion criterion was applied: the presence of columnar-lined esophageal segments of any length detected on endoscopy and subsequently confirmed by histological examination. Mucosal biopsies were taken from the distal esophagus of 92 patients with GERD during upper endoscopy (EGD) and then examined by the pathologists. Of all the examined patients, 42 had BE, 24 had $\mathrm{CM}$ extending $>1 \mathrm{~cm}$ above GEJ (COM1.5 to C13M14) and 26 patients had endoscopic features of $\mathrm{CM}<1 \mathrm{~cm}$ above GEJ (COM0.3-0.8). Exclusion criteria were as follows: the absence of columnar metaplasia in the biopsy histological examination; the absence of esophageal mucosa components in the biopsied specimens (stratified squamous epithelium, glands of the esophageal lamina propria and their ducts), especially in ultrashort BE, which prevented us from drawing a firm conclusion that the biopsies had been collected from the esophagus but not from the stomach. In the group of patients with $\mathrm{CM}<1 \mathrm{~cm}$ above GEJ, the mean age was $55.50 \pm 1.10$ years (range 22-82 years); of them 11 were men (mean age $50.09 \pm 18.03$ ) and 15 women (mean age $59.47 \pm 14.57$ ); the male to female ratio was $1: 1.36$. The group of patients with $\mathrm{CM}$ segment length $>1 \mathrm{~cm}$ consisted of 24 individuals aged 19-94 years (mean age $52.21 \pm 18.00$ ); of them 7 were male (mean age $47 \pm 20.05$ ) and 17 were female (mean age $53.5 \pm 17.47$ ); the male to 
female ratio was $1: 2.4$. The group of patients with $B E$ was represented by 42 patients aged 19-93 years (mean age $61.80 \pm 16.33$ ); of them 29 were men (mean age $54.47 \pm 21.79$ ) and 13 women $(69.23 \pm 13.57)$; the male to female ratio was 2.23 : 1 . The patients with $\mathrm{CM}$ length $<1 \mathrm{~cm}$ and $>1 \mathrm{~cm}$ tended to be younger than those with $\mathrm{BE}$, but the difference between the groups was insignificant. In the group with $\mathrm{CM}$ $<1 \mathrm{~cm}$ and $\mathrm{CM}>1 \mathrm{~cm}$ above GEJ, as well as in the BE group, the mean age of male participants was lower than that of women, because the male sex is one of the risk factors for GERD.

Pre-existing conditions predisposing our patients to the $\mathrm{CM}$ of the distal esophagus and BE included sliding hiatal hernia and cardiac sphincter incompetence. Endoscopy was suggestive of sliding hiatal hernia in 14 of 26 (53.8\%) patients who had endoscopic evidence of $\mathrm{CM}<1 \mathrm{~cm}$; another $3(11.5 \%)$ patients with $\mathrm{CM}<1 \mathrm{~cm}$ had signs of cardiac sphincter incompetence in the absence of hiatal hernia. In the group with $\mathrm{CM}$ extending $>1 \mathrm{~cm}$ above GEJ, hiatal hernia was detected by EGD in $11(45.83 \%)$ patients and cardiac sphincter incompetence, in $3(12.5 \%)$ individuals. Of all study participants with BE, endoscopy was suggestive of hiatal hernia in $18(42.86 \%)$ patients and of cardiac sphincter incompetence, in 6 (14.29\%) participants.

Biopsied esophageal specimens were processed following the standard protocol. The slides were stained with hematoxylineosin and Schiff reagent-Alcian blue. The latter helps to identify goblet cells and discriminate between goblet and dystrophic pseudogoblet cells. Pseudogoblet cells were detected in $88.04 \%$ of all examined specimens.

Biopsies with intestinal metaplasia were evaluated for the density of goblet cells in the glands. If goblet cells made less than $5 \%$ of all epithelial cells in the glands, the sample was categorized as containing few goblet cells; if these cells amounted to 5-50\% of all epithelial cells, the sample was categorized as containing lowdensity goblet cells; if the proportion of goblet cells exceeded $50 \%$, the sample was regarded as containing high-density goblet cells.

All biopsies collected from the patients with $\mathrm{CM}<1 \mathrm{~cm}$ were analyzed for the presence of esophageal mucosa components, including stratified squamous epithelium (20 patients, 76.92\%), esophageal glands (19 patients, 73.07\%) and their excretory ducts (5 patients, 19.23\%). This helped us to determine whether the studied specimens had been collected from the distal esophagus vs the stomach. The fragments that lacked the aforementioned components of the esophageal mucosa were excluded from the final analysis.

In 24 cases of $\mathrm{BE}$ and $\mathrm{CM}>1 \mathrm{~cm}$ above GEJ, immunohistochemistry was performed using the following

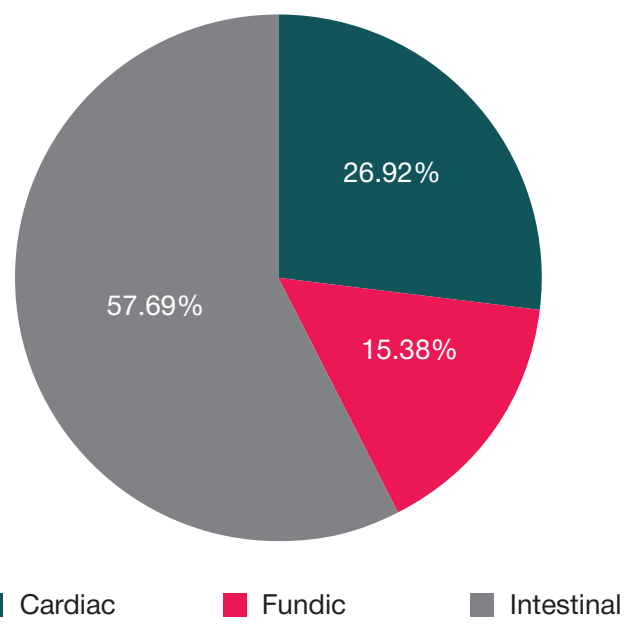

Fig. 1. Prevalence of different metaplasia types in CM segments extending $<1 \mathrm{~cm}$ above GEJ antibodies: anti-MUC1 (1: 100, Ventana; Roche), anti-MUC2 (1 : 125, Ventana; Roche), anti-MUC5A (1: 250, Ventana; Roche), anti-MUC6 (ready to use, Ventana; Roche), anti-CDX2 (1: 125, Ventana; Roche), and anti-Villin (ready to use, Leica).

\section{RESULTS}

Three metaplasia types were identified in the patients with $\mathrm{CM}<1 \mathrm{~cm}$ above GEJ: cardiac, fundic and intestinal. In the absence of other metaplastic changes, cardiac-type metaplasia was present in 7 (26.92\%) patients and fundic-type, in 4 patients (15.38\%) in the group with $\mathrm{CM}<1 \mathrm{~cm}$ (Fig.1). Intestinal metaplasia with different relative goblet cell density was observed in 15 patients (57.69\%) (Fig. 2). In 5 patients (33.33\%), goblet cells were few. Low-density goblet cells (10 to $49 \%)$ were observed in 8 patients (53.33\%); high-density goblet cells (50 and $70 \%)$, in 2 patients (13.33\%). Biopsies of 6 patients (23.07\%) contained a mosaic of 3 metaplasia types. Esophagitis was a pre-existing condition in all study participants. Inflammatory cell infiltration was moderate in $69.23 \%$ of specimens and pronounced in $30.77 \%$ of cases. Erosions of esophageal mucosa were observed in 8 patients (30.77\%); ulceration was detected in 1 patient. Biopsies of 9 patients (34.62\%) were described as indefinite for dysplasia (reactive changes of the epithelium characterized by the irregular arrangement and crowding of the glands, their angulated shape, slightly enlarged and hyperchromic nuclei, and single mitotic cells). In 2 specimens, reactive changes of the epithelium were observed in the presence of cardiac-type metaplasia; in 6 cases, in the presence of intestinal metaplasia with low density of goblet cells; in 1 case, in the presence of intestinal metaplasia with high density of goblet cells. Lowgrade or high-grade dysplasia was not detected in any of the esophageal specimens with $\mathrm{CM}<1 \mathrm{~cm}$.

In the group with $\mathrm{CM}>1 \mathrm{~cm}$ above GEJ, cardiac-type metaplasia was detected in 14 of 24 patients (58.33\%), whereas fundic, in 10 individuals $(41.67 \%)$. The group of patients with BE included 42 individuals with intestinal metaplasia. If we merge these two groups into one, the ratio of metaplasia types will be as follows (Fig. 3): cardiac type, 14 of 66 patients (21.21\%), fundic type, 10 (15.15\%), intestinal type, 42 (63.64\%). The mosaic of all 3 types was observed in 8 patients with BE (12.12\%). In the BE group (42 patients with intestinal metaplasia; Fig. 4), few goblet cells were detected in 8 participants (18.18\%); low-density goblet cells, in 15 individuals (43.09\%); high-density goblet cells, in 21 patients (47.73\%).

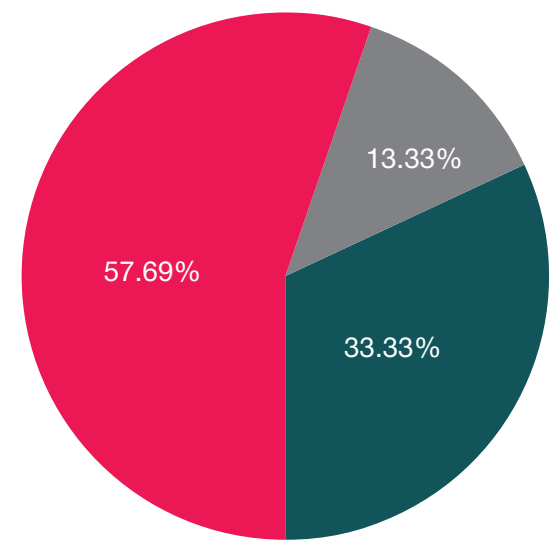

Few cells

Low density

High density

Fig. 2. The relative number of goblet cells in $\mathrm{CM}$ segments extending $<1 \mathrm{~cm}$ above GEJ 
Thus, intestinal metaplasia was more prevalent in the biopsies of patients with $\mathrm{CM}>1 \mathrm{~cm}$ above GEJ and BE than in the group with $\mathrm{CM}<1 \mathrm{~cm}$ above GEJ (63.64 and 57.69\% respectively; Fig. 5). High-density goblet cells occurred in the patients with $\mathrm{BE} 3.5$ times more often than in those with $\mathrm{CM}<1 \mathrm{~cm}$ (Fig. 6).

Signs of esophagitis with moderate inflammatory lymphocyte/plasma cell infiltration were detected in 16 patients with $\mathrm{CM}>1 \mathrm{~cm}$ above GEJ (66.67\%), whereas signs of pronounced inflammation, in 8 patients (33.33\%). Erosions of the metaplastic mucosa were present in 11 patients (45.83\%); of them 1 patient had areas of ulceration. Reactive changes of the epithelium were observed in 5 patients with columnar metaplasia (20.83\%); of them 3 had cardiac type and 2, fundic type. One patient was found to have high-grade dysplasia of the metaplastic segment in the presence of cardiac-type metaplasia (4.2\%).

Signs of esophagitis with moderate inflammatory lymphocyte/plasma cell infiltration were detected in 18 patients with BE (42.86\%), whereas signs of pronounced inflammation, in 26 patients (57.14\%); 27 patients had erosions of metaplastic esophageal segments (64.29\%), of them 4 individuals had areas of ulceration. Erosions were detected 2.1 times more often in the patients with $\mathrm{BE}$ than in those with $\mathrm{CM}<1 \mathrm{~cm}$ above GEJ and 1.4 times more often than in the patients with CM $>1 \mathrm{~cm}$ above GEJ. Reactive changes of the epithelium were observed in 15 patients (35.71\%). Thus, reactive changes of the epithelium occurred with the same frequency in the patients with $\mathrm{BE}$ and $\mathrm{CM}<1 \mathrm{~cm}$ above GEJ and were 1.7 more rare in the patients with $\mathrm{CM}>1 \mathrm{~cm}$ without intestinal metaplasia. Reactive changes of the epithelium were significantly more frequent in the patients with $\mathrm{BE}$ than in those with $\mathrm{CM}>1 \mathrm{~cm}$ above GEJ (Mann-Whitney $U$ test; $p<0.05)$. Such changes were equally prevalent in the samples differing in the density of goblet cells (few goblet cells, low density of goblet cells and high density of goblet). In all cases, the changes were associated with the severity of inflammation (Mann-Whitney $U, p<0.05$ ).

Low- or high-grade dysplasia was absent in the patients with $\mathrm{CM}<1 \mathrm{~cm}$. Low-grade dysplasia (Fig. 7A) was diagnosed in 8 patients with BE (19.05\%); of them 6 patients had highdensity goblet cells and 2 , single goblet cells. One patient with $\mathrm{CM}>1 \mathrm{~cm}$ was found to have high-grade dysplasia (4.2\%; Fig. 7B).

Eight specimens of $\mathrm{CM}>1 \mathrm{~cm}$ and 16 specimens of $\mathrm{BE}$ were tested for the markers of intestinal (MUC2, CDX2, Villin) and gastric (MUC1, MUC5A, MUC6) differentiation using

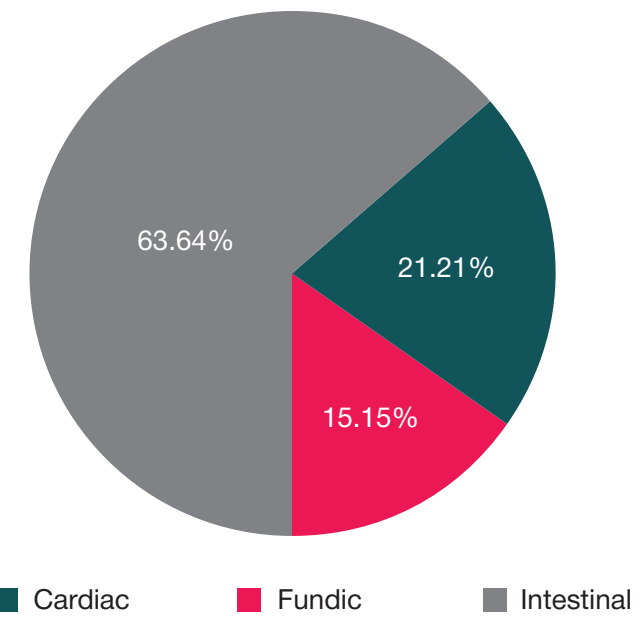

Fig. 3. Prevalence of different types of columnar metaplasia in different parts of the biopsied segment $>1 \mathrm{~cm}$ above GEJ, including BE immunohistochemistry assays. Samples with cardiac and fundic-type metaplasia were characterized by strong diffuse expression of MUC5A in the cytoplasm of the surface epithelial layer, weak diffuse expression of MUC1 in the cytoplasm of the surface epithelial layer, diffuse expression of MUC1, MUC5A and MUC6 in the cytoplasm of glandular epithelium. MUC2 was not expressed in the samples with cardiac or fundic-type metaplasia. CDX2 was expressed in 5 patients with cardiac and fundic-type metaplasia (in up to $30 \%$ of the cells in the biopsied fragment); Villin expression was noted in 8 cases (in 15-20 to $80 \%$ of glandular epithelial cells). Expression of intestinal markers (CDX2 and Villin) in the samples with cardiac and fundic-type metaplasia is a sign of submorphological enteralization. In our study, intestinal markers (MUC2, CDX2, Villin) were expressed in all 16 patients with BE and intestinal metaplasia. Their expression depended on the density of goblet cells: cytoplasmic expression of MUC2 was observed in 10 to $50 \%$ of the cells; nuclear expression of CDX2 was discovered in 10 to $90 \%$ of epithelial cells, including cells of the columnar glandular epithelium with the cardiac phenotype; cytoplasmic expression of Villin was detected in $70-100 \%$ of epithelial cells. Because goblet cells in the metaplastic BE epithelium are interspersed with foveolar cells, intestinal metaplasia is also characterized by the expression of gastric markers: MUC1, MUC5A and MUC6, which seems to be weaker than in cardiactype metaplasia and not so spread out.

The immunohistochemical analysis of BE fragments with low-grade dysplasia revealed pronounced expression of MUC2, CDX2 and Villin and weak expression of MUC1, MUC5A and MUC6. MUC1, MUC5A, MUC6, and Villin were also expressed in one sample with high-grade dysplasia and cardiac-type metaplasia negative for MUC2 and CDX2 expression.

\section{DISCUSSION}

This study compares morphological phenotypes of columnarlined epithelium segments extending $<1 \mathrm{~cm}$ above GEJ, $>1 \mathrm{~cm}$ above GEJ, and BE segments. Interestingly, our groups of patients with $\mathrm{CM}>1 \mathrm{~cm}$ and $\mathrm{BE}$ were almost mirrorsymmetrical in terms of male to female ratio: for the patients with $\mathrm{CM}>1 \mathrm{~cm}$, the male to female ratio was $1: 2.4$, whereas for the patients with $B E$, it was $2.23: 1$. In all groups, the mean age of male participants was a bit lower than the mean age of women because the male sex is one of the risk factors for GERD. It is believed that cardiac-type metaplasia is the earliest type of CM in patients with GERD. In our study, in the

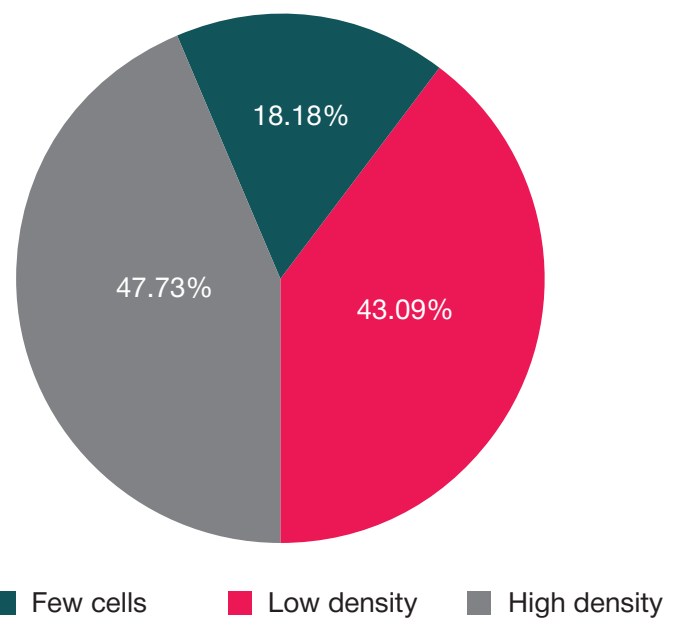

Fig. 4. The relative number of goblet cells in BE segments. 
absence of other metaplastic changes cardiac-type metaplasia was detected more frequently in the patients with $\mathrm{CM}<1 \mathrm{~cm}$ (26.92\%) than in C0M1.5-C13M14 biopsies (21.21\%). Goblet cells occurred more frequently in the metaplastic segments $>1 \mathrm{~cm}$ in length; high-density goblet cells were seen 3.5 times more often in the patients with $\mathrm{CM}<1 \mathrm{~cm}$ than in those with $\mathrm{CM}<1 \mathrm{~cm}$. According to the literature, the frequency of goblet cell occurrence increases with the length of the metaplastic esophageal segment [6]. In our next study, we will be attempting to establish a correlation between the length of the BE segment, the frequency of goblet cell occurrence and their density.

Reactive changes of the epithelium were observed significantly more often in the group of patients with BE vs the group with $\mathrm{CM}>1 \mathrm{~cm}$ above GEJ and were associated with the severity of inflammation (Mann-Whitney $U, p<$ 0.05). In the patients with BE, dysplasia was detected more often (19.05\%) than in the patients with $\mathrm{CM}>1 \mathrm{~cm}(4.2 \%)$. Biopsies characterized by low-grade dysplasia in the presence of BE showed pronounced expression of intestinal (MUC2, CDX2, Villin) and weaker expression of gastric (MUC1, MUC5A, MUC6) markers, which is consistent with the mixed metaplastic phenotype dominated by intestinal metaplasia $[13,14,18-20]$. The only case of high-grade dysplasia with $\mathrm{CM}>1 \mathrm{~cm}$ was characterized by bright expression of MUC1, MUC5A, MUC6, and Villin and was negative for MUC2 and CDX2 expression, suggesting the cardiac phenotype. Thus, we

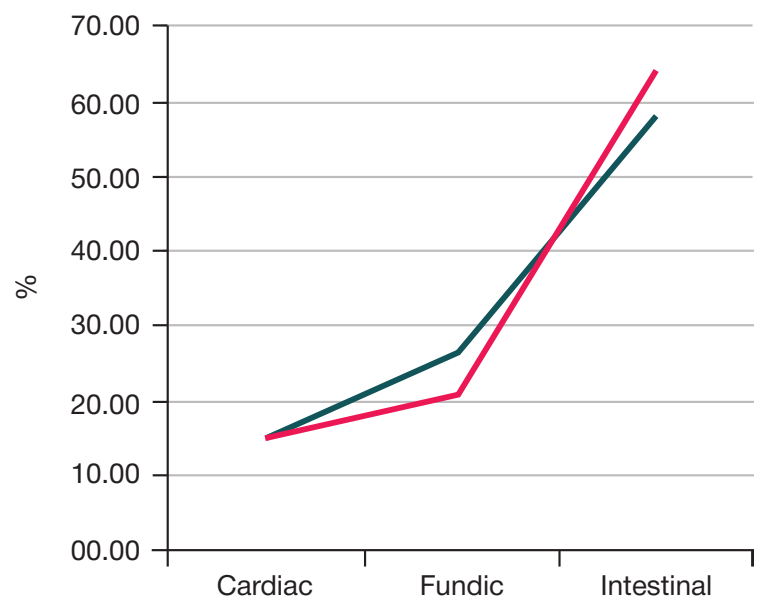

Columnar metaplasia

$<1 \mathrm{~cm}$ above GEJ

Columnar metaplasia

$>1 \mathrm{~cm}$ above GEJ

Fig. 5. The relative number of different metaplasia types in $\mathrm{CM}$ segments $<1 \mathrm{~cm}$ and $>1 \mathrm{~cm}$ above GEJ

A

Low-grade dysplasia

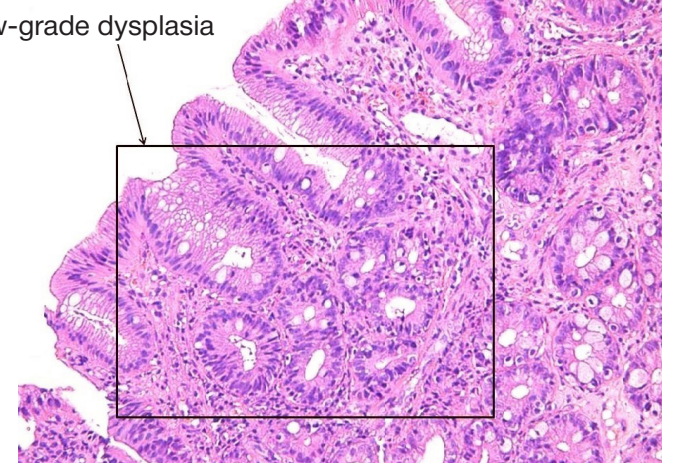

observed both intestinal (BE) and foveolar (CM $>1 \mathrm{~cm}$ above GEJ) carcinogenesis pathways, but the intestinal one prevailed in our sample, in spite of the miniature size of the dysplastic focus ( $\geq 2 \mathrm{~mm}$ ).

It is hypothesized that high density of goblet cells can be protective against dysplasia [16, 17]. In our sample, low-grade dysplasia was detected in 6 of 8 biopsies (75\%) characterized by high density of goblet cells in the adjacent esophageal mucosa. This can be explained by a small number of lowgrade dysplasia cases in our patient sample. Further research is needed to provide a more objective morphological profile for patients with $\mathrm{BE}$ in the early stage of dysplasia and to identify the group at risk for this condition.

\section{CONCLUSIONS}

The accuracy of ultra-short BE diagnosis largely depends on precise targeting during biopsy sampling. This diagnosis can be established only if the biopsied specimen contains esophageal components (stratified squamous cell epithelium, excretory ducts and glands of the mucosa) and shows distinct metaplastic changes in the esophageal epithelium. Our comparative analysis of biopsy samples revealed that reactive changes in the epithelium were more frequent in the $\mathrm{BE}$ segments than in the specimens with $\mathrm{CM}>1 \mathrm{~cm}$ above GEJ (Mann-Whitney $U, p<0.05$ ); in the group with $\mathrm{CM}<1 \mathrm{~cm}$, these

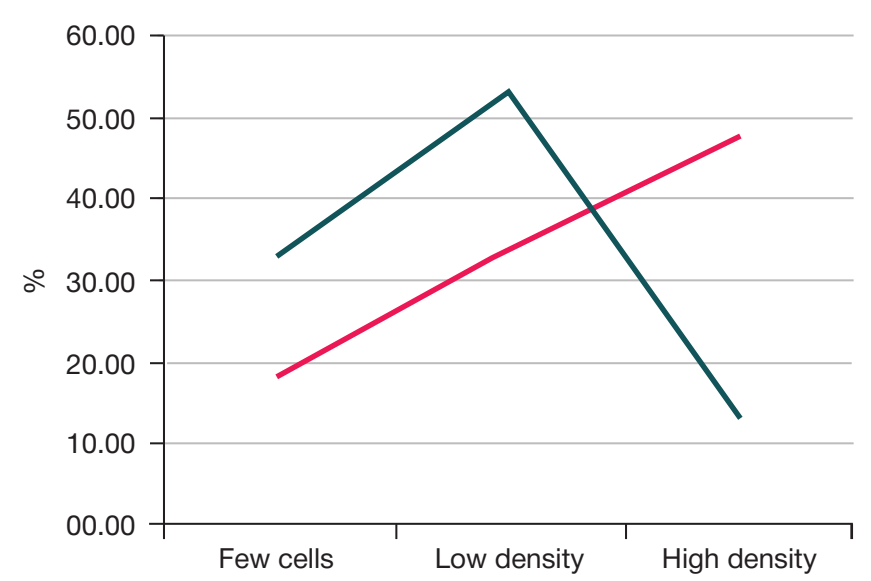

The relative number of goblet cells in $\mathrm{CM}$

segments extending $<1 \mathrm{~cm}$ above GEJ

The relative number of goblet cells

in BE segments

Fig. 6. The relative number of goblet cells in $\mathrm{CM}$ segments $<1 \mathrm{~cm}$ above GEJ and in BE segments

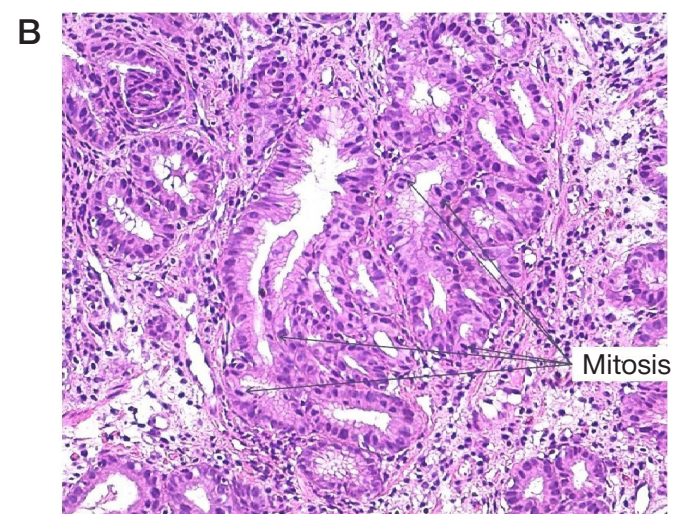

Fig. 7. A. Low-grade esophageal dysplasia in patients with BE. B. High-grade esophageal dysplasia in patients with $\mathrm{CM}>1 \mathrm{~cm}$ above GEJ. Staining: hematoxylineosin; magnification $\times 200$ 
changes were observed more often in the presence of goblet cells. Reactive changes in the epithelium were associated with the severity of esophagitis. Genuine dysplasia was detected in 8 patients with BE (low-grade dysplasia, 19.05\%) and in 1 patient with $\mathrm{CM}>1 \mathrm{~cm}$ above GEJ (high-grade dysplasia,
4.2\%). Immunohistochemical testing for the intestinal and gastric markers of cell differentiation revealed the signs of submorphological enteralization in all esophageal specimens with cardiac and fundic type metaplasia and in the specimens with $\mathrm{BE}$ in the areas lacking goblet cells.

\section{References}

1. Shaheen NJ, Falk GW, lyer PG, Gerson LB. ACG clinical guideline: diagnosis and management of Barrett's esophagus. Am $J$ Gastroenterol. 2016; 111 (1): 30-50. PubMed PMID: 26526079.

2. Fitzgerald $\mathrm{RC}$, di Pietro $\mathrm{M}$, Ragunath $\mathrm{K}$, Ang $\mathrm{Y}$, et al. British Society of Gastroenterology guidelines on the diagnosis and management of Barrett's oesophagus. Gut. 2014; (63): 7-42. PubMed PMID: 24165758.

3. Bennett C, Moayyedi P, Corley DA, DeCaestecker $J$ et al. BOB CAT: A Large-Scale Review and Delphi Consensus for Management of Barrett's Esophagus With No Dysplasia, Indefinite for, or Low-Grade Dysplasia. Am J Gastroenterol. 2015; (110): 662-82. PubMed PMID: 25869390.

4. Montgomery EA, Canto MI, Srivastava A. Evaluation and reporting of biopsies from the columnar-lined esophagus and gastroesophageal junction (GEJ). Ann Diagn Pathol. 2019; (39): 111-7. PubMed PMID: 30802810.

5. Biswas S, Quante M, Leedham S, Jansen M. The metaplastic mosaic of Barrett's oesophagus Virchows Archiv. 2018; (472): 43-54. PubMed PMID: 29500519

6. Harrison R, Perry I, Haddadin W, McDonald S, et al. Detection of intestinal metaplasia in Barrett's esophagus: an observational comparator study suggests the need for a minimum of eight biopsies. Am J Gastroenterol. 2007; (102): 1154-61. PubMed PMID: 17433019

7. Que J, Garman KS, Souza RF, Spechler SJ. Pathogenesis and Cells of Origin of Barrett's Esophagus. Gastroenterology. 2019; 157 (2): 349-64. PubMed PMID: 31082367.

8. Theodorou D, Ayazi S, DeMeester SR, Zehetner J, et al. Intraluminal $\mathrm{pH}$ and goblet cell density in Barrett's esophagus. J Gastrointest Surg. 2012; (16): 469-74. PubMed PMID: 22095525.

9. Sun D, Wang X, Gai Z, Song X, Jia X, Tian H. Bile acids but not acidic acids induce Barrett's esophagus. Int J Clin Exp Pathol. 2015; 8 (2): 1384-92. PMID: 25973022.

10. Hahn HP, Blount PL, Ayub K, Das KM, et al. Intestinal differentiation in metaplastic, nongoblet columnar epithelium in the esophagus. Am J Surg Pathol. 2009; (33): 1006-15. PubMed PMID: 19363439

11. Bhat S, Coleman HG, Yousef F, Johnston BT, et al. Risk of malignant progression in Barrett's esophagus patients: results from a large population-based study. 2011; J Natl Cancer Inst. 103 (13): 1049-57. PubMed PMID: 21680910.

\section{Литература}

1. Shaheen NJ, Falk GW, lyer PG, Gerson LB. ACG clinical guideline: diagnosis and management of Barrett's esophagus. Am J Gastroenterol. 2016; 111 (1): 30-50. PubMed PMID: 26526079.

2. Fitzgerald $R C$, di Pietro $M$, Ragunath $K$, Ang $Y$, et al. British Society of Gastroenterology guidelines on the diagnosis and management of Barrett's oesophagus. Gut. 2014; (63): 7-42. PubMed PMID: 24165758.

3. Bennett C, Moayyedi P, Corley DA, DeCaestecker $J$ et al. BOB CAT: A Large-Scale Review and Delphi Consensus for Management of Barrett's Esophagus With No Dysplasia, Indefinite for, or Low-Grade Dysplasia. Am J Gastroenterol. 2015; (110): 662-82. PubMed PMID: 25869390.

4. Montgomery EA, Canto MI, Srivastava A. Evaluation and reporting of biopsies from the columnar-lined esophagus and gastroesophageal junction (GEJ). Ann Diagn Pathol. 2019; (39): 111-7.
12. Kelty CJ, Gough MD, Van Wyk Q, Stephenson TJ, Ackroyd R Barrett's oesophagus: intestinal metaplasia is not essential for cancer risk. Scand J Gastroenterol. 2007; 42 (11): 1271-4. PubMed PMID: 17852872.

13. Takubo K, Aida J, Naomoto Y, et al. Cardiac rather than intestinal type background in endoscopic resection specimens of minute Barrett adenocarcinoma. Hum Pathol. 2009; 40 (1): 65-74. PubMed PMID: 18755496.

14. Watanabe G, Ajioka Y, Takeuchi M, Annenkov A, Kato T, et al. Intestinal metaplasia in Barrett's oesophagus may be an epiphenomenon rather than a preneoplastic condition, and CDX2-positive cardiac-type epithelium is associated with minute Barrett's tumour. Histopathology. 2015; 66 (2): 201-14. PubMed PMID: 25040564

15. Lavery DL, Martinez P, Gay LJ, Cereser B, et al. Evolution of oesophageal adenocarcinoma from metaplastic columnar epithelium without goblet cells in Barrett's oesophagus. Gut. 2016; 65 (6): 907-13. PubMed PMID: 26701877.

16. Schellnegger R, Quante A, Rospleszcz S, Schernhammer M, et al. Goblet cell ratio in combination with differentiation and stem cell markers in Barrett esophagus allow distinction of patients with and without esophageal adenocarcinoma. Cancer Prev Res. (Phila). 2017; 10 (1): 55-66. PubMed PMID: 27807078.

17. Srivastava A, Golden KL, Sanchez CA, Liu K, et al. High goblet cell count is inversely associated with ploidy abnormalities and risk of adenocarcinoma in Barrett's esophaqus. PLoS One. 2015; 10 (7): e0133403. PubMed PMID: 26230607.

18. Agoston AT, Srivastava A, Zheng $Y$, et al. Prevalence and concordance of subtypes of dysplasia in patients with Barrett's esophagus-associated adenocarcinoma. Mod Pathol. 2014; (27): 162a-162a.

19. Demicco EG, Farris AB, Baba Y, Agbor-Etang B, et al. The dichotomy in carcinogenesis of the distal esophagus and esophagogastric junction: intestinal-type vs cardiac-type mucosaassociated adenocarcinoma. Mod Pathol. 2011; (24): 1177-90. PubMed PMID: 21572404

20. Khor TS, Alfaro EE, Ooi EM, Li Y, et al. Divergent expression of MUC5AC, MUC6, MUC2, CD10, and CDX-2 in dysplasia and intramucosal adenocarcinomas with intestinal and foveolar morphology: Is this evidence of distinct gastric and intestinal pathways to carcinogenesis in Barrett esophagus? Am J Surg Pathol. 2012; (36): 331-42. PubMed PMID: 22261707.

PubMed PMID: 30802810.

5. Biswas S, Quante M, Leedham S, Jansen M. The metaplastic mosaic of Barrett's oesophagus Virchows Archiv. 2018; (472): 43-54. PubMed PMID: 29500519

6. Harrison R, Perry I, Haddadin W, McDonald S, et al. Detection of intestinal metaplasia in Barrett's esophagus: an observational comparator study suggests the need for a minimum of eight biopsies. Am J Gastroenterol. 2007; (102): 1154-61. PubMed PMID: 17433019

7. Que J, Garman KS, Souza RF, Spechler SJ. Pathogenesis and Cells of Origin of Barrett's Esophagus. Gastroenterology. 2019; 157 (2): 349-64. PubMed PMID: 31082367.

8. Theodorou D, Ayazi S, DeMeester SR, Zehetner J, et al Intraluminal $\mathrm{pH}$ and goblet cell density in Barrett's esophagus. J Gastrointest Surg. 2012; (16): 469-74. PubMed PMID: 
22095525.

9. Sun D, Wang X, Gai Z, Song X, Jia X, Tian H. Bile acids but not acidic acids induce Barrett's esophagus. Int J Clin Exp Pathol. 2015; 8 (2): 1384-92. PMID: 25973022.

10. Hahn HP, Blount PL, Ayub K, Das KM, et al. Intestinal differentiation in metaplastic, nongoblet columnar epithelium in the esophagus. Am J Surg Pathol. 2009; (33): 1006-15. PubMed PMID: 19363439

11. Bhat S, Coleman HG, Yousef F, Johnston BT, et al. Risk of malignant progression in Barrett's esophagus patients: results from a large population-based study. 2011; J Natl Cancer Inst. 103 (13): 1049-57. PubMed PMID: 21680910.

12. Kelty CJ, Gough MD, Van Wyk Q, Stephenson TJ, Ackroyd R. Barrett's oesophagus: intestinal metaplasia is not essential for cancer risk. Scand J Gastroenterol. 2007; 42 (11): 1271-4. PubMed PMID: 17852872.

13. Takubo K, Aida J, Naomoto Y, et al. Cardiac rather than intestinal type background in endoscopic resection specimens of minute Barrett adenocarcinoma. Hum Pathol. 2009; 40 (1): 65-74. PubMed PMID: 18755496.

14. Watanabe G, Ajioka Y, Takeuchi M, Annenkov A, Kato T, et al. Intestinal metaplasia in Barrett's oesophagus may be an epiphenomenon rather than a preneoplastic condition, and CDX2-positive cardiac-type epithelium is associated with minute Barrett's tumour. Histopathology. 2015; 66 (2): 201-14. PubMed PMID: 25040564.

15. Lavery DL, Martinez P, Gay LJ, Cereser B, et al. Evolution of oesophageal adenocarcinoma from metaplastic columnar epithelium without goblet cells in Barrett's oesophagus. Gut. 2016; 65 (6): 907-13. PubMed PMID: 26701877.

16. Schellnegger R, Quante A, Rospleszcz S, Schernhammer M, et al. Goblet cell ratio in combination with differentiation and stem cell markers in Barrett esophagus allow distinction of patients with and without esophageal adenocarcinoma. Cancer Prev Res. (Phila). 2017; 10 (1): 55-66. PubMed PMID: 27807078.

17. Srivastava A, Golden KL, Sanchez CA, Liu K, et al. High goblet cell count is inversely associated with ploidy abnormalities and risk of adenocarcinoma in Barrett's esophagus. PLoS One. 2015; 10 (7): e0133403. PubMed PMID: 26230607.

18. Agoston AT, Srivastava A, Zheng $Y$, et al. Prevalence and concordance of subtypes of dysplasia in patients with Barrett's esophagus-associated adenocarcinoma. Mod Pathol. 2014; (27): 162a-162a.

19. Demicco EG, Farris AB, Baba $Y$, Agbor-Etang B, et al. The dichotomy in carcinogenesis of the distal esophagus and esophagogastric junction: intestinal-type vs cardiac-type mucosaassociated adenocarcinoma. Mod Pathol. 2011; (24): 1177-90. PubMed PMID: 21572404

20. Khor TS, Alfaro EE, Ooi EM, Li Y, et al. Divergent expression of MUC5AC, MUC6, MUC2, CD10, and CDX-2 in dysplasia and intramucosal adenocarcinomas with intestinal and foveolar morphology: Is this evidence of distinct gastric and intestinal pathways to carcinogenesis in Barrett esophagus? Am J Surg Pathol. 2012; (36): 331-42. PubMed PMID: 22261707. 